\title{
Bioreactors and Their Applications in Biotechnology
}

\author{
Sonali Mohapatra* \\ Department of Biotechnology, Ravenshaw University, Odisha, 753001, India
}

\begin{abstract}
A bioreactor is the unit of biological process which holds biologically active environment. It is a vessel which contains biological materials used for growing organisms (yeast, bacteria or animal cells) under controlled conditions ensuring the same temperature, $\mathrm{pH}^{\mathrm{n}}$ and $\mathrm{O}_{2}$ levels. Their sizes differ from few mm ${ }^{3}$ to 500 $\mathrm{m}^{3}$. The various kinds of bioreactors which have different industrial applications. This review extensively focuses on the different types of bioreactors and their applications in the bio-transformation of the enzymes (amylase, lipase, cellulose etc.), medicines and recombinant proteins.
\end{abstract}

Keywords: STR, BCR, ARL, PBR, FBR, Photobioreactor

\section{Introduction}

Bioreactor is an apparatus containing biological materials which is used for growing organism (yeast, bacteria or animal cells) under controlled conditions ensuring the same temperature, $\mathrm{pH}$ and $\mathrm{O}_{2}$ levels. It is also used in the conversation of raw materials into beneficial by-products (e.g. corn into ethanol). The raw material can be of non-chemical or additive compound. The converted product may be Saccharomyces cerevisiae, acellular protein, bacterial cultures, forage or the metabolites involved in normal growth, organic acids, nutrients. A bioreactor is the unit of biological process which holds biologically active environment. In it, chemical reactions are carried out involving living organisms (aerobic or anaerobic) or biologically active substances produced from the organism. It can be used for the bio-transformation of the enzymes (amylase, lipase, cellulose etc.), medicines and recombinant proteins. A bioreactor commonly gives bio-mechanical and biotechnological environment that controls nutrient and $\mathrm{O}_{2}$ transfer to the cells and the metabolic products from the cells [1-3].

Bioreactors are mainly cylindrical and ranges in size from a liter to some cube meter. The dimension of the bioreactor can differ extensively from bacterium cell $\left(\mathrm{few} \mathrm{mm}^{3}\right)$ to shake flask $(100-1000 \mathrm{ml})$ to lab scale fermenter $(1-50 \mathrm{~L})$ to pilot level $\left(0.3-10 \mathrm{~m}^{3}\right)$ to plant scale $\left(2-500 \mathrm{~m}^{3}\right)$ for huge manufacturing in the factories [4]. The bioreactor's condition like gas (i.e. air, $\mathrm{O}_{2}, \mathrm{~N}_{2}, \mathrm{CO}_{2}$ ) flow rates, temperature, $\mathrm{pH}$ and liquefied oxygen levels and agitation momentum rate, foam production etc. need to be intimately detected and managed [5]. It is a multiplex structure consisting of pipes, fittings, wires and sensors visible to functional complications. We can now find out if any mistake is going on during the process [6].

\section{Types of Bioreactors}

Majority of biological reaction systems can be categorized into 2 main groups: suspension systems and immobilization systems. Suspension systems include stirred tank bioreactors (STRs), bubble column bioreactor and airlift bioreactor whereas fluidized bed bioreactor, packed bed bioreactor and photo bioreactors are included in the immobilization system.

\section{Continuous Stirred Tank Bioreactor (CSTR)}

Stirred tank bioreactor is the conventional and vital bioreactor in the industrial applications because it has lower operational costs. The STR that works in a continuous operation with feeding and removal of mass and energy is defined as continuous stirred tank bioreactor (CSTR) [7]. It is consisting of a cylindrical shaped container with motor driven central shaft that bears one or more agitators (impellers) (Figure 1) [8]. There are two types of CSTRs used in the industrial process: Chemostat: needed for the cell culture into which all nutrients are mixed and the volume of liquid is kept constant by arranging the inlet and outlet flow rates same and Turbidostat: where the cell congregation is maintained constant ocular solidity of the culture and the fluid magnitude is kept sustained by arranging the outlet flow rate to the inlet flow rate [9]. It has various advantages like easy scale up, fine liquid adding and $\mathrm{O}_{2}$ transfer potentiality and alternative impellers.

\footnotetext{
*Correspondence to: Sonali Mohapatra, Department of Biotechnology, Ravenshaw University, Odisha, 753001, India, E-mail: precioussonali10@gmail.com Citation: Mohapatra S (2020) Bioreactors and Their Applications in Biotechnology. J Catal Chem Eng Adv 7(1): 104. DOI: https://doi.org/10.47275/2693-7182-104.

Received: July 05, 2020; Accepted: July 18, 2020; Published: August 01, 2020

Copyright: (c) 2020 Mohapatra S. This is an Open Access article distributed under the terms of the Creative Commons Attribution 4.0 International License (CCBY) (http://creativecommons.org/licenses/by/4.0/) which permits commercial use, including reproduction, adaptation, and distribution of the article provided the original author and source are credited.
} 


\section{Bubble Column Bioreactor (BCR)}

These are the simplest type of bioreactors which are extensively used in sensitive cell cultures such as filamentous fungus cells, mammalian cells and plant cells [10]. Commonly it comprises of a cylindrical shaped vessel with a gas distributor at the base which pushes gas bubbles into a fluid stage or a liquid-solid suspension (Figure 2) [11]. BCRs have the advantages like high durability of the catalyst, addition of online catalyst, withdrawal ability [12]. The design of BCR mainly follows three phenomena which are: heat, mass transfer and chemical kinetics [13]. These reactors are applied in the synthetic, chemical, petrochemical, biochemical and metallurgical industries for methanol synthesis, synthetic fuel production and hairy root culture of the plant cells $[10,14]$.

\section{Air Lift Bioreactor (ARL)}

It is nothing but the variation of BCR (Figure 3) [15]. There is a central tube which is responsible for efficient mixing and recirculation of fluid. There are two primary configurations in the air lift bioreactor as: external loop reactors and internal loop reactors. In the former, the fluid circulates through distinct channels whereas the circulation of fluid follows the central and peripheral channel in the later [16]. It can be used for free and immobilized cells and suitable for yeast, fungi, plant and animal cells. They are generally employed for aerobic bioprocessing technology. Sometimes these are also used in the production of methanol and acellular protein and in the waste water treatment method.

\section{Packed Bed Bioreactors (PBRs)}

The Packed bed bioreactors (PBRs) typically consist of a packed-bed of solid particles that supports the cells on or within carriers and a reservoir that is used to re-circulate the oxygenated nutrient medium through the bed (Figure 4) [15]. The solids used may be permeable or non-permeable gels, and they may be compressible or rigid in nature. A nutrient broth flows continuously over the immobilised biocatalyst.

A lot of authors presented the prospective of the use of PBRs as "artificial organs" [17] in biomedical applications. A relatively popular example of such application is the bioartificial liver device (BAL) [18].

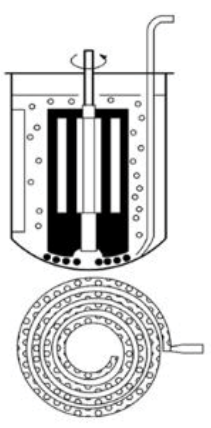

(a)

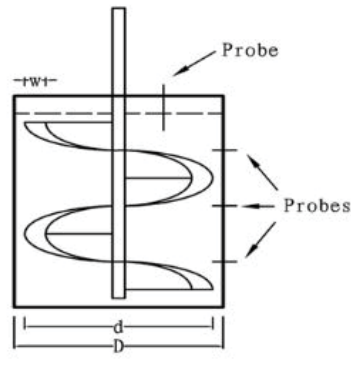

(b)

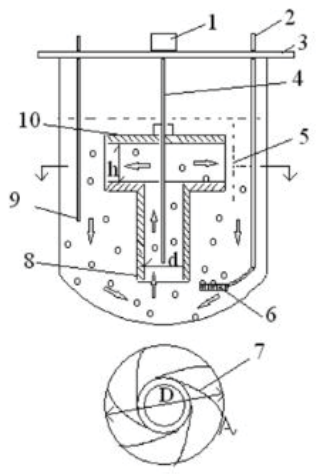

Figure 1: Schematic diagram of stirred-tank bioreactors (STRs) with different impellers.(a): Gate paddle bioreactor with a spiral sparger (b): Helical ribbon impeller bioreactor (c): Centrifugal impeller bioreactor. (1- Stirrer, 2- Gas in, 3- Head plate, 4- Shaft, 5- Measuring points for 6- Sparger, 7- Blade, 8- Draft tube, 9- DO probe, 10- Rotating pan [8]

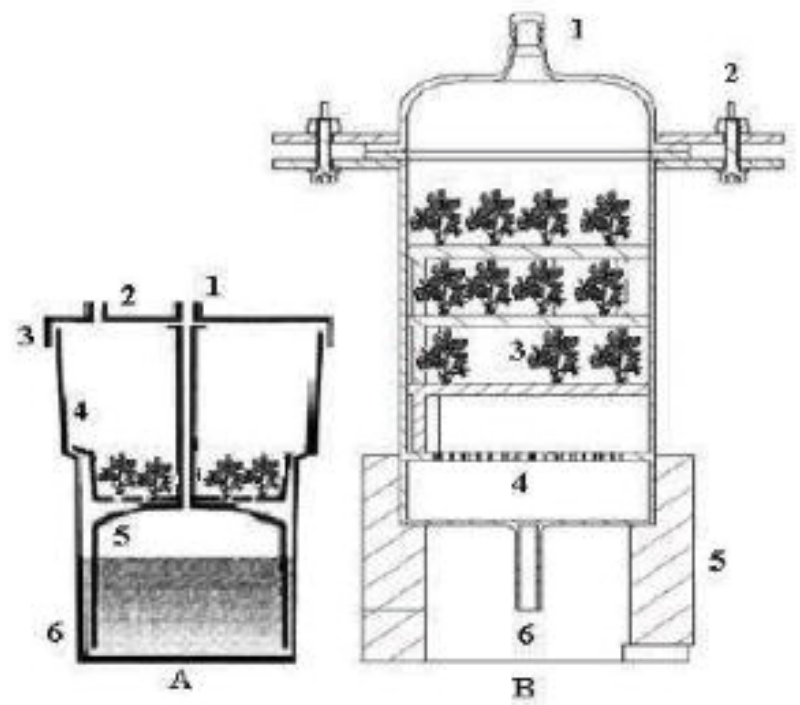

Figure 2: Bubble column reactor. (A): Front view and (B): Side view of a Bioreactor of Immersion by Bubbles;1-Air exhausting, 2- Screws, 3-Metallic perforated trays 4-Porous plate distribution, 5-Support brackets, 6- Air inlet [12]. 


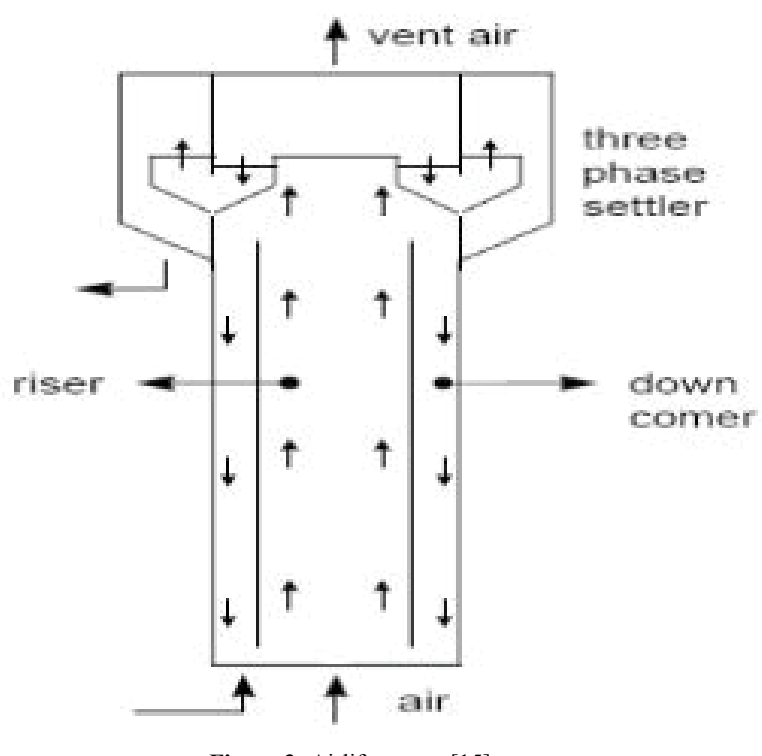

Figure 3: Airlift reactor [15].

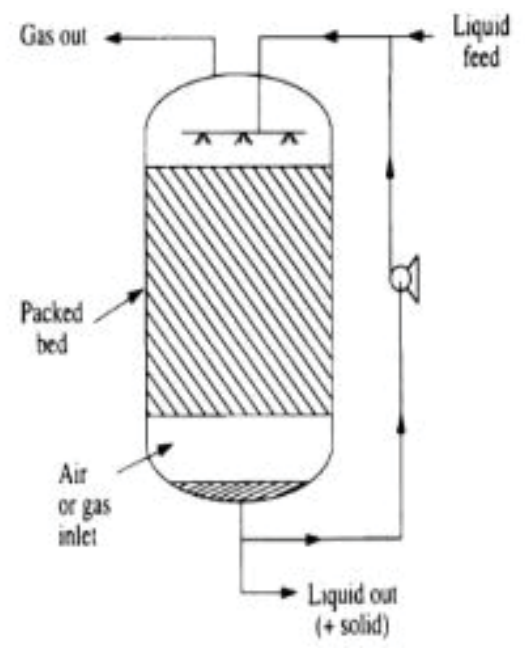

Figure 4: Packed bed reactor [15].

\section{Fluidized Bed Reactor (FBR)}

Fluidized bed reactors (FBRs) comprise packed bed with miniature magnitude particles [19]. The model of the FBR (expanded top and narrow reaction column) is in such a way that the solids are employed in the reactor while the liquid emanates (Figure 5) [20]. These bioreactors are suitable for carrying out reactions involving fluid suspended biocatalysts such as immobilized enzymes, immobilized cells, and microbial flocs.

\section{Photo Bioreactors}

These are mainly used in photosynthetic process which involves vegetable biomass growth or microalgae growth under controlled conditions [21]. These are the bioreactors exclusively used for the fermentation that can be carried out either by exposing to sunlight or artificial illumination (Figure 6) [21]. According to Ugwu et al, there are different types of photobioreactors: continuous run tubular loop, multiple parallel tube, helical wound tubular loop and flat plate configuration.

\section{Applications of Bioreactors in Biotechnological Process}

\section{Growth of cells and tissues}

Bioreactors play a crucial role in the cell and tissue-based therapy used to develop red blood cells, chimeric antigen receptor (CAR) T cells, induced pluripotent stem cells, and mesenchymal stem cells. There are several kinds of bioreactors which are used in maintaining microenvironments to regulate cell growth, differentiation and development of tissue [22].

\section{Enzyme production}

Membrane bioreactors are used extensively in production of glucose from cellulose using enzyme recycling [23]. Erwinia chrysanthemi cells 


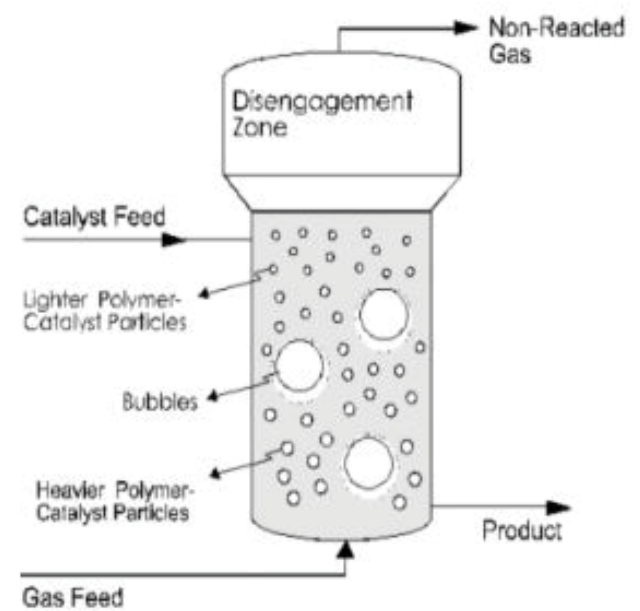

Figure 5: Fluidized bed reactor [20]
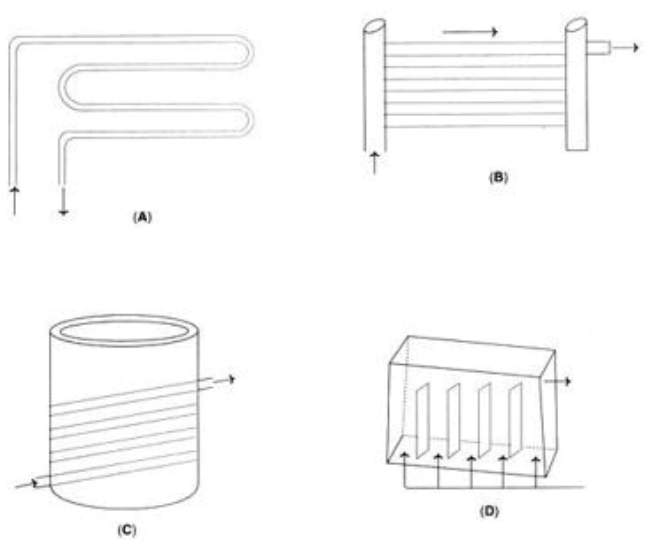

Figure 6: Types of photobioreactors: A- Continuous run tubular loop, B- Multiple parallel tube, C- Helical wound tubular loop, D- Flat panel configuration [21].

were used to produce bacterial enzymes in a membrane bioreactor coupled with a membrane filtration unit [24].

\section{Biocatalysts}

By using new membrane bioreactors, we can convert the biocon version of organic compounds by utilizing the application of biofilms of fungal and bacterial cells and their enzymes, including hydrolases, polyphenol oxidase, peroxidase and laccase [25].

\section{Aroma production}

Flavor and aroma molecules (FAMs) are additives which increase the flavour of the food. Now using the multiphase bioreactor (partitioning bioreactors), the productivity of several bioprocesses can be improved due to their great potential [26].

\section{Algal biomass production}

A biofilm bioreactor has been developed which increases speed of microalgae production for the use of feed and biofuel. One of the advantages includes, the algae grown on a membrane should be easier to collect than in other systems [27].

\section{Recombinant protein production}

Now-a-days bioreactors play a vital role in the large-scale production of recombinant protein using the yeast Yarrowia lipolytica in order to facilitate decision-making for future strain and process engineering [28].

\section{Conclusion}

Bioreactors play a crucial role in biotechnological processes which interlinks between the raw materials and final products. Bioreactors have been used for decades to manufacture a range of therapeutic biomolecules and other high-value products. Typically, they are used in the culture of vegetable, algal, microbial and mammalian cells in obtaining product of interest. They provide a way to monitor and control environmental conditions continuously throughout the culture/reaction period along with the added benefit of maintaining a closed system. They are critical and integral part of the development of many new biotechnological processes. 


\section{References}

1. Sharma KR. 2012. Design and operational key factors of bioreactor. Biotech Articles.

2. Bueno EM, Bilgen B, Carrier RL, Barabino GA. 2004. Increased rate of chondrocyte aggregation in a wavy-walled bioreactor Biotechnol Bioeng 88(6): 767-777.https://doi.org/10.1002/ bit.20261

3. Haj AJE, Wood MA, Thomas P, Yang Y. 2005. Controlling cell biomechanics in orthopaedic tissue engineering and repair. Pathol Biol (Paris) 53(10): 581-589.https://doi.org/10.1016/j. patbio.2004.12.002

4. https://www.ncsu.edu/biosucceed/courses/BioreactorEngineering.pptx

5. Chen H-C, Hu Y-C. Bioreactors for tissue engineering. Biotechnology Letters 28(18): 1415-1423.https://doi.org/10.1007/s10529-006-9111-x

6. Cinar A, Parulekar SJ, Undey C, Birol G. 2003. Batch fermentation:modeling monitoring and control. CRC Press.https://doi.org/10.1201/9780203911358

7. Spier MR, Vandenberghe L, Medeiros ABP, Soccol C. Application of different types of bioreactors in bioprocesses. 2011.

8. Zhong JJ. 2010. Recent advances in bioreactor engineering. Korean J Chem Eng 27(4): 1035-1041.https://doi.org/10.1007/s11814-010-0277-5

9. Laska ME, Cooney CL. 2002. Bioreactors, Continuous Stirred-Tank Reactors.https://doi.org/10.1002/0471250589.ebt030

10. Kantarci N, Fahir B. 2008. Department of Chemical Engineering, Bogaziç University, 34342, Bebek-Istanbul, Turkey.

11. Spier MR, Vandenberghe L, Medeiros ABP, Soccol C. 2011. Application of different types of bioreactors in bioprocesses. Nova Scientific Publishers. 55-90.

12. Soccol CR, Pandey A, Larroche C. 2013. Fermentation processes engineering in the food industry. Tylor and Francis group.https://doi.org/10.1201/b14070

13. Borakb, Ulgena KO. Department of Chemical Engineering, Yeditepe University, 34755, Kadikoy-Istanbul, Turkey.

14. Degaleesan S, Dudukovic M, Pan Y. 2004. Experimental study of gasinduced liquid-flow structures in bubble columns. AIChE Journal 47(9): 1913-1931.https://oi.org/10.1002/ aic.690470904

15. Siegel MH, Robinson CW. 1992. Applications of airlift gas-liquid-solid reaction in biotechnology. Chem Eng Sci 47(13-14): 3215-3229.https://doi.org/10.1016/0009-2509(92)85030-f

16. Flickinger MC, Drew SW. 2002. Encyclopedia of bioprocess technology: fermentation, biocatalysis and bioseparation.https://doi.org/10.1002/0471250589

17. Allen JW, Hassanein T, Bhatia SN. 2003. Advances in bioartificial liver devices. Hepatology 34(3): 447-455.https://doi.org/10.1053/jhep.2001.26753

18. Allen JW, Bhatia SN. 2002. Improving the next generation of bioartificial liver devices. Cell Dev Biol 13(6): 447-454.https://doi.org/10.1016/s1084952102001337

19. Singh J, Kaushik N, Biswas S. 2014. Bioreactors- technology and design analysis. The Scitech Journal.

20. Kwong WH. 2000. An improved simplified model predictive control algorithm and its application to a continuous fermenter. Braz J Chem Eng 17(2): 143-161.https://doi.org/10.1590/ s0104-66322000000200003

21. Ugwu CU, Aoyagi H, Uchiyama H. 2008. Photobioreactors for mass cultivation of algae, Bioresour Technol 99(10): 4021-4028.https://doi.org/10.1016/j.biortech.2007.01.046

22. Stephenson M, Grayson W. 2018. Recent advances in bioreactors for cell-based therapies. F1000Res 7: 517.https://doi.org/10.12688/f1000research.12533.1

23. Shokrkar H, Ebrahimi S, Zamani M. 2018. A review of bioreactor technology used for enzymatic hydrolysis of cellulosic materials. Cellulose 25(11): 6279-6304.https://doi.org/10.1007/ s10570-018-2028-4

24. Denis S, Boyaval P. 1991. Microbial enzyme production in a membrane bioreactor. Biochem Eng J34(5): 608-612.https://doi.org/10.1007/bf00167908

25. Burton SG. 2001. Development of bioreactors for application of biocatalysts in biotransformations and bioremediation. Pure Appl Chem 73(1): 77-83.https://doi.org/10.1351/ pac200173010077

26. Palmerin-Carreno DM, Cordero-Soto IN, Valle-Cervantes S, Rios-Nunez LG, Prado-Barragan LA, et al. 2019. Multiphase bioreactors in the food industry: aroma production. Adv Chem Engineer Sci 54: 151-193.https://doi.org/10.1016/bs.ache.2019.01.004

27. https://www.feednavigator.com/Article/2017/08/11/New-bioreactor-to-speed-production-of-microalgae-for-feed-fuel-uses.

28. Vandermies M, Fickers P. 2019. Bioreactor-scale strategies for the production of recombinant protein in the yeast Yarrowia lipolytica. Microorganisms 7(2): 40.https://doi.org/10.3390/ microorganisms 7020040 